\title{
Side by Side - Hohfeld and Somló on Rights and Duties
}

\author{
MiKLÓs SZABó*
}

\begin{abstract}
Somlós main work - [Juristische Grundlehre Foundations of Law] and the appearance of Hohfeld's last study - Fundamental Legal Conceptions... II. However, there is a greater connection between the two authors. Their work is intertwined by the impact of John Austin and the aspiration to introduce results of analytical philosophy of law to the spiritual community of lawyers, mostly being averse from this branch of philosophy. The common topos of their works was the conceptual problem of right/duty and the far reaching impact of their handling of the problem. The exposition of the problem did not come from nowhere but arouse from the intellectual mold of the age - the turn of $20^{\text {th }}$ century. In their elaborations, they have long lasting impact, initiating scholarly debates to current times. It is argued that though their conceptual world differed, it is better to conclude that their results complemented, rather than destroyed each other and it is possible to integrate them in one overall conception.
\end{abstract}

Keywords: Somló, Hohfeld, Neo-Kantian jurisprudence, analytical jurisprudence, rights and duties, fundamental legal conceptions and relations

2017 was the $100^{\text {th }}$ year anniversary of the publication of Somlós Juristische Grundlehre. ${ }^{1}$ At the same time, another illustrious representative of early $20^{\text {th }}$ century jurisprudence is being commemorated - Wesley Newcomb Hohfeld. ${ }^{2}$ The parallelism between the paths of their professional lives and their significance for their respective scholar communities makes it possible to compare their works, with special regard to one of the leading topics of the time - the conception of rights and duties. The excellence of these authors is unquestionable but the question of their significance for present day scholarship arises. This paper sketches the parallels between the two scholars lives and work. The intention of this work is to present that two theorists, so distant from each other in space and working among so different circumstances may arrive at similar, at least compatible answer to the same question posed by modern systems of law (Part 1). The next section (Part 2) delineates the origin of the rights problem and rights debate forming the context of the authors conceptions - their answers to the question of rights. By this point, it should become obvious that Somló and Hohfeld have not arrived out of the blue but they had predecessors, both in Europe and in the USA. This makes necessary to highlight the main decisive sources of conceptions of rights - Austin and Bierling (Part 3). The paper ends with a summing up and an evaluation the results of Hohfeld and Somló, by throwing light on the commensurability of their results (Part 4).

1.

The presupposition of this comparison is that it is not just a sheer coincidence that two bright scholars from completely different historical, cultural and legal conditions, separated

* Professor of Law at Institute for History and Theory of Law, School of Law, University of Miskolc, Hungary; e-mail: jogszami@uni-miskolc.hu

1 Somló (1917).

2 A two-day workshop was organised at Yale Law School, on 14-15 October, 2016: Symposium (2016) link 1; and a commemorative publication is forthcoming: Balganesh et alii (2018). 
by thousands of kilometers and not being aware of each other, arrive at the same question and offer similar, at least compatible answers. There must have been 'something in the air' of those 'revolutionary' opening years of the $20^{\text {th }}$ century which forced out new insights. In law and the theory of law, it was the challenge to explore the building bricks and basic work of modern positive systems of law.

Looking at the comparative outlines of their careers, it can be seen that both Hohfeld and Somló lived comparatively short, fruitful but tragic lives. Somló was six years older than Hohfeld but these extra years were wasted by Somló whilst trying to find a way to academic life. Nonetheless, Somló's academic life-span lasted for 20 years (1900-1920) whilst Hohfeld's was only for 8 years. The peak of Hohfeld's career was reached in 1913 when issuing Some Fundamental Legal Conceptions... and was crowned by earning a professorship at Yale Law School in 1914. Somló's peak point can be identified as the year of publication of Juristische Grundlehre - 1917. The high days were soon followed by a tragic end for both of them. Hohfeld's obituary reported that his death was the result of endocarditis which followed a severe attack of grippe. ${ }^{3}$ The shock caused by the post-war collapse of Hungary lead Somló to return to Kolozsvár, the city where his academic capacities flourished and committed suicide in 1920.

\begin{tabular}{|c|c|c|}
\hline W. N. Hohfeld & year & F. Somló \\
\hline & 1873 & $\begin{array}{l}\text { born in Pozsony/Pressburg/Bratislava on } 21 \\
\text { July }\end{array}$ \\
\hline \multirow[t]{3}{*}{ born in Oakland, California on 8 August } & 1879 & \\
\hline & 1896 & $\begin{array}{l}\text { degree in law at U. of Kolozsvár/ } \\
\text { Klausenburg/Cluj }\end{array}$ \\
\hline & $1896-1902$ & army, study tours to Germany, practice ${ }^{4}$ \\
\hline BA degree at U. of California & 1901 & \\
\hline studies at Harvard Law School & 1902 & $\begin{array}{l}\text { lecturer at Nagyvárad/Großwardein/Oradea } \\
\text { Academy of Law }\end{array}$ \\
\hline degree at Harvard Law School & 1904 & professorship at U. of Kolozsvár \\
\hline legal practice & 1904-1905 & \\
\hline lecturer to professorship at Leland Stanford & 1905 & \\
\hline Some Fundamental Legal Conceptions & 1913 & \\
\hline professorship at Yale Law School & 1914 & \\
\hline Fundamental Legal Conceptions & 1917 & Juristische Grundlehre \\
\hline \multirow[t]{2}{*}{ died in Almeda, California on 21 October } & 1918 & \\
\hline & 1920 & died in Kolozsvár on 28 Sept. \\
\hline \multirow[t]{2}{*}{ first posthumous edition of collected works ${ }^{5}$} & 1923 & \\
\hline & 1926 & posthumous edition of Prima Philosophia ${ }^{6}$ \\
\hline
\end{tabular}

Table 1. Comparative lifespan of Hohfeld and Somló

3 Editorial (1918) 166, 167.

4 1896/97: volunteer military service, eight month clerkship in a law firm, two semesters in Leipzig and Heidelberg, then clerkship at the State Railway Company.

5 Cook (1923).

${ }^{6}$ Somló (1926). 
The common root shared by these men leads back to the legacy of John Austin. 'Mr. Austin, who had no fortune [to combine some gainful occupation with his professorship] and who regarded the study and exposition of his science as more than sufficient to occupy his whole life and who knew that it would never be in demand amongst the immense majority of law students who regarded their profession only as a means of making money, found himself under the necessity of resigning his Chair. [...] This was the real and irremediable calamity of his life - the blow from which he never recovered. ${ }^{7}$ The same pitfalls were experienced both by Somló and Hohfeld, followed by the same disappointments. Somló's experience on 5 October 1914 was 'University lectures have begun. [...] The course in jurisprudence was attended by some nine sophomores, with the usual blasé face of our law students that puts the extinguisher on you.' ${ }^{8}$ A report regarding Hohfeld's conflict with his students, at roughly the same time stated 'Hohfeld's teaching at Yale began in the autumn of 1914. He was a severe taskmaster, requiring his students to master his classification of fundamental conceptions and to use accurately the set of terms by which they were expressed. [The students] found this, in the light of the usage of the other professors, almost impossible. [...] Rumours of the terms of [Hohfeld's] contract with Yale [i.e., that the way back was assured for Hohfeld] reached them and led to the belief that he had only a one-year appointment. Most of them signed a petition addressed to President Hadley asking that his appointment be not extended. ${ }^{99}$ Immediately after learning of the petition, Hohfeld sent a final resignation to Stanford in order to clarify the situation.

Further common features of their personalities are reflected by these episodes. The personalities' first striking feature was their deep commitment to erudition - not just to jurisprudence, but to legal scholarship as the strict science of law. ${ }^{10}$ Exactly this possibility seemed to be offered by the analytical school of law. Furthermore, if someone is convinced of analytics being the proper way of cultivating jurisprudence and, at the same time, they are a moral professor with an uncompromising personality, they have no choice but to teach the same in the classroom - no matter whether it is popular among students. ${ }^{11}$

In any event, this resulted in a sort of unworldliness or otherness for both of them, making them feel uncomfortable in their surroundings. '[Hohfeld] was not a person naturally comfortable in the world. Indeed, given Corbin's description of Hohfeld's behaviour and his expressed grounds for resisting a move to Yale, he might well be understood to be at the very high functioning end of Asperger's Spectrum Disorder.' ${ }^{12}$

7 Sarah Austin referring to the obituary appearing in Law Magazine and Review (May, 1860) in her 'Preface' to Austin (1911) 9.

8 Somló's Diary vol. 3 (24 July 1914 - 13 Nov. 1917).

9 Foreword by Arthur L. Corbin to Hohfeld (1964) X.

10 An obituary remembered Somló as follows: 'It is sure, that Somló could be characterised by indefatigable, almost intractable thinking, enormous logical force, insight, careful inference, belonging to the small group of bright thinkers. In general, all that marks an inspired scholar, a brain endowed with creative thought.' Bárd (1921) 35.

11 This conviction was proven by Hohfeld (1914); and Somló (1920), as a study book, a 130page Hungarian extraction from the German Grundlehre, titled Jogbölcsészet (Jurisprudence), not long before his tragic death.

12 Schlegel (2016) link 2. 34. Corbin's description can be found in a letter he wrote to E. V. Rostow, 10 Aug. 1957 (see Thomas Swan Papers, Yale University Library and Hohfeld Family Papers). There 'he remembered Hohfeld's 'manner (except to a close friend) to be cold'; he was impatient 'with what he regarded as incompetence' and 'often gave offense both socially and intellectually'. He was, at times 'so 'frank' in his criticisms that it was painful to his associates who were present'.' Ibid. 25. 
Somló himself did not seem to be suffering from any serious disease but often complained of gnawing headaches (probable migraines) and his diary tells of cyclic mood swings. ${ }^{13}$ The deepest point of Somló's mood was feeling desperation because of unsuccessful attempts to find an academic position - 'I am feeling forced to give up everything I have been striving for ever since I can remember and I have to choose such a way as my walk in life that I hate, that I am not apt for and that will never please me. Had I not parents, I would blow my brains out.' This note was just a joke but two years later, Somlós brother Gustav committed suicide and a psychologist could have found it noteworthy. ${ }^{14}$

Beside similarities, there are also differences between the two. First, they diverged from their common Austinian root in different directions: Hohfeld turned from general jurisprudence towards particular jurisprudence and legal doctrine ${ }^{15}$ while Somló took a turn towards the philosophy and even metaphysics of law. ${ }^{16}$ The next difference is that the volume of their work differs sharply: Hohfeld bequeathed some 420 pages whilst Somló's work contained circa 2,200 pages. ${ }^{17}$ Thirdly, the context or frame of reference of their interpretation is determined by their legal context: Hohfeld is rooted in common law while Somló is in civil law systems. This results in a different style of explication: Hohfeld's argumentation is essayistic while Somló's is rather monographic. The final difference is their subsequent impact: Hohfeld's small work had a big impact on future generations, Somló's big work had a much smaller impact on contemporary legal thought.

2.

The topos that connected Somló's and Hohfeld's labour was the problem of rights. The background of emergence had taken shape by the turn of the $20^{\text {th }}$ century, a great time for almost every branch of scholarship. The final headwaters of the emergence of the problem can be identified in legal positivism. For both Anglo-American and European Continental streams of positivism, the problem of rights culminated in the question of whether rights are possible without a foundation in positive law. What in English language terminology is covered by the terms right and law is expressed in one word, the same word in most Continental languages, Recht, droit, diritto, etc., needs adjectives to specify the meaning. The most common way is the use of subjective and objective adjectives e.g., subjektives Recht, objektives Recht. Legal right may be offered and used as a common denominator which is acceptable for both streams of positivism. Founding in positive law makes it possible to build the momentum of coercion into the concept of right (and law). That is why a right is able to be defined as not just as something that 'belongs', but which can be 'claimed'. The seriousness of this claim is assured by the (final) enforceability with the help of state authorities.

13 Somló's Diary vol. 2, 5 September 1898.

14 On Somló's life and work in details see Funke (Böhlau 2013).

15 'He was interested in theory only so far as it would help lawyers, judges and legislators to develop the law scientifically.' The words of the obituary on Hohfeld; Editorial (1918) 168.

16 To quote the obituary on Somló in more detail: 'We hardly have proper perspective to declare for even the probable impact of Somló's teachings, and in order to evaluate his philosophy we have to wait if we want to see whether the direction taken by him proves to be the permanent direction of the future.' Bárd (1921) 36. Looking back, we have to admit: it did not fit the anti-metaphysical stream of the twentieth century.

17 Later, a glimpse of their plans left behind will be taken. 
However, recalling Singer, a concept of law embedded in a liberal theory of law interferes with a contradiction between freedom and security - 'Thus, the contradiction is between the principle that individuals may legitimately act in their own interest to increase their wealth, power and prestige at the expense of others and the principle that they have a duty to look out for others and to refrain from acts that hurt them. [...] The contradiction between freedom of action and security therefore translates into the contradiction between individual rights and state powers. ${ }^{\prime}{ }^{18}$ In the language of law the contradiction leads to tension between the simultaneous claims for freedom to act guaranteed by the state and the claim for freedom from others intervention in their freedom, i.e., defence (guaranteed by the state) against others' freedom to act. The contradiction cannot be resolved but can be handled.

For resolution, some meta-theory is needed that is capable of reconciling opposing claims. The contours of that theory are drawn differently by private lawyers and public lawyers. Theories of public lawyers are self-evidently state-centric as, being sensitive to the overwhelming power of the state, they try to control its intervening power with constitutional rights or division of powers. ${ }^{19}$ On the opposite end, private lawyers tend to leave the state out of account and attend solely to private citizens legal relations. It is easy to recognise that continental Europe can be characterised by the public law orientation, while the AngloSaxon world is dominated by the private law orientation.

The theoretical mould from which theories of rights emerged, was critical concept analysis and its results were embodied in clear, sharp concepts able to grasp and handle their objects. The program of critical concept analysis was undertaken by the school of 'analytical philosophy'. Its origin in the Anglo-Saxon history of ideas can be located in the work of John Austin (1790-1859) and his master, Jeremy Bentham (1748-1832); on the Continent it can be bound to the school of Neo-Kantianism, with Immanuel Kant's (1724-1804) critical philosophy in the background. These two schools are connected by their common impulse, ${ }^{20}$ even if their $20^{\text {th }}$ century histories followed different directions. The connectedness of analytical and Neo-Kantian schools is reflected by Roscoe Pound, as well: 'In the analytical school we may distinguish four forms: (1) The Austinians, whose method is exclusively analytical. Holland's Jurisprudence is the leading book of this type. (2) The later English analytical jurists, or Neo-Austinians, as Jethro Brown called them. Their method was historical as well as analytical. They sought to reconcile and to combine analytical and historical method. (3) More recently, a tendency toward philosophy appeared among English analytical jurists [Salmond, Goadby]. (4) A Neo-Kantian analytical type arose in Continental Europe in the second decade of the present century - Kelsen's

18 Singer (1982) 980. The insolubility of the dilemma is illustrated by Singer in one of his epigraphs with a tale told by Abraham Lincoln on the sheep and the wolf who do not (and cannot) agree upon the definition of the word 'liberty' (i.e. liberty to eat and liberty not to be eaten).

19 From the same epoch see e.g. Laband (2004); Jellinek (1892); Kelsen (1911). As an overview see Sólyom (2016).

20 '[The analytical] method consists in examination of the structure, subject matter, and precepts of a legal system in order to reach by analysis the principles, theories, and conceptions which it presupposes, and to organize the authoritative materials of judicial and administrative determination on this logical basis. It postulates, or takes as the ideal, a body of logically interdependent precepts.' Pound (1959) 17. 
pure theory of law. It combines a neo-critical philosophy of law with an analytical jurisprudence.'21

In general, Kelsen used to be labelled being legal positivist, normativist and NeoKantian. What then is analytical in Kelsen? First, as a matter of fact he was strongly impressed by John Austin and he made considerable impact on Hart. Herbert Hart described Kelsen as 'the most stimulating writer on analytical jurisprudence of our day. ${ }^{22}$ Kelsen can be held a follower of Austin when explaining law as 'coercive order', although he declined both the concept of sovereign and sanction as constitutive elements of a concept of law. Second, he labelled his own work the 'pure theory of law'. Purity was aimed at a most analytical target: to elaborate a pure, i.e., formal concept of (positive) law via his Grundnorm. He knew well that his pure theory of law 'corresponds in important points with Austin's doctrine. ${ }^{23}$ He maintained insistence to his analytical roots later in 1945 'The orientation of the pure theory of law is in principle the same as that of so-called analytical jurisprudence. [...] Where they differ, they do so because the pure theory of law tries to carry on the method of analytical jurisprudence more consistently than Austin and his followers. ${ }^{24}$ It can be supposed that Kelsen would have not been against being classified as an 'analytical' thinker.

The two schools are connected, among other aspects, by the central role they assign to (state) coercion when disclosing the conception of law. This served as a fundamental thesis for establishing the concept of law during the $19^{\text {th }}$ and the first half of $20^{\text {th }}$ century - up to Hart's opus magnum. 'After Hart, most writers working in analytical jurisprudence simply took it as given that coercion was not part of the concept of law as such and hence was at best secondary in importance to other features of law from a theoretical point of view (however salient it might be in practice). The outstanding exception here was Ronald Dworkin, who held that a conception of law must explain how what it takes to be law provides a general justification for the exercise of the coercive power of the state that holds except in special cases when some competing argument is specially powerful.« It was no doubt in part his influential example that led the third-generation figures to maintain this commitment in face of massive opposition by Hart, his very prominent student Joseph Raz and their many capable followers. ${ }^{25}$

21 Pound (1969) 62-3. Others do not draw Neo-Kantian and analytical schools together but keep them apart. See e.g. Bowie (2010) Chapter 7. On the other hand Robert Hanna goes as far as to say: 'The history of analytic philosophy from Frege to Quine is the history of the rise and fall of the concept of analyticity, whose origins and parameters both lie in Kant's first Critique.' Hanna (2001) 121.

22 Hart (1962) 728.

${ }^{23}$ Kelsen (1941) 54.

${ }^{24}$ Kelsen (1961) xv.

25 Trejo-Mathys (2015) 149. For the citation see Dworkin (1986) 190. Glock (2015) while calling up the commonplace about diagonal philosophical opposition (as conservative vs. revolutionary streams) of the two schools, underlines important points of agreement and influence through Frege, Wittgenstein and some logical positivists. Anyhow, we content ourselves with the claim that there is at least one interest - in analyzing concepts - of the two and the claim about parallelism (not causation) between them. Glock (2015) 72 establishes five points common between mainstream NeoKantianism and analytic philosophy: dichotomy of a priori and a posteriori knowledge; a prioristic conception of philosophy; connecting philosophy to science; logocentrism: ascribing a central role to logic; anti-psychologism. 
3.

The two branches of analytical positivism, the American and continental European, each had their own leading figures, who laid the conceptual foundation for understanding and reflecting developments in law. Two figure stand out from the rest of the academics: Austin and Bierling.

\section{1.}

Standing on Bentham's shoulders, ${ }^{26}$ John Austin, 'the strictest of the analytical jurists' according to Gray, ${ }^{27}$ became the father of analytical school of law. It is widely known that he built his theory upon three necessary concepts: the (general) command (of sovereign), (correlative) duty and of sanction (as enforcement of obedience). ${ }^{28}$ Taking into regard that these necessary concepts of law presuppose a command or coercion theory of law, it seems self-evident that there is not any rights theory in Austin's case. There is, at the least, a sort of duty theory from which the concept of rights may be derived posteriorly. The first Lecture of The Province... is devoted to clarifying the confusion around the terms law and a law (rule) which finally concludes that rights and duties are correlative pairs. However, while laws imposing sheer duties (without correlative rights) are possible, they are absolute duties - laws ensuring sheer rights (without correlative, explicit or implicit, duties) would not be imperative, so they could not form a part of positive law (with Austin's words: 'a law properly so called'). His conclusion regarding the conception of rights is rather dismissive - 'The meanings of the term right, are various and perplexed; taken with its proper meaning, it comprises ideas which are numerous and complicated...' ${ }^{29}$ However, the delay in elucidating the concept of right and the context in which it found room, make it clear that the concept of right did not count as a basic concept of law for Austin.

The starting point of analysis, therefore, is the correlative couple of right and duty, within which 'right' is the derivate of 'duty'. In the same way, 'duty' is the derivate of (sovereign) 'power'. 'The party invested with a right, is invested with that right by virtue of the corresponding duty imposed upon another or others. And this duty is enforced, not by the power of the party invested with the right, but by the power of the state. The power resides in the state; and by virtue of the power residing in the state, the party invested with the right is enabled to exercise or enjoy it. ${ }^{30}$ At this point the road divides. One line of the junction is the power of the state which, in an ideal typical case means full powers, being entitled to a sovereign person or body, allowing no limitation. 'Limited monarchy, therefore, is not monarchy' says Austin referring to Hobbes Leviathan ${ }^{31}$ i.e., it is contradiction in terms. Of course, limited power may exist - as oligarchy, aristocracy or democracy. However, this possibility will not be developed by Austin, who contents himself by claiming

${ }^{26}$ For Bentham's conception of rights - especially for rights-with-duties, permissive rights and legal powers - see e.g. Chapter 'Legal Rights' in Hart (Oxford UP 1982).

27 Gray (1909) 4.

${ }^{28}$ Lecture I. of The Province... It is clear '...that command, duty and sanction are inseparably connected terms: that each embraces the same ideas as the others, though each denotes those ideas in a peculiar order or series.' Austin (1911) 91-2. He uses 'duty' instead of 'obligation' because the origin of the latter in Roman Law was exclusively used to denote the correlative of a right in personam.

${ }^{29}$ Austin (1911) 100. Austin goes back to the concept of rights in Lectures XLV-XLVI under the title 'Law of Things'.

30 Austin (1911) 398, Lecture XVI. (Emphasis added.)

31 Austin (1911) 241, Lecture VI. 
that 'The rights which are pursued against it before tribunals of its own and also the rights which it pursues before tribunals of its own, are merely analogous to legal rights (in the proper acceptation of the term): or (borrowing the brief and commodious expressions by which the Roman jurists commonly denote an analogy) they are legal rights quasi, or legal rights $u t i$. - The rights which are pursued against it before tribunals of its own, it may extinguish by its own authority., ${ }^{32}$

The other line of the junction leads towards the transferability of power, that is (using Continental terminology) towards the possibility of subjective power, ensured by objective (positive) law, objektives Recht, following the design of subjective right, subjektives Recht. Subjects may possess power in two different roles. The first is as subjects (e.g. as judges) subordinated to a supreme power (government) they may participate in making a command, establishing some legal duty, ensured by some sanction i.e., a (positive) law. 'Although they are made directly by subject or subordinate authors, they are made through legal rights granted by sovereigns or states and held by those subject authors as mere trustees for the granters. ${ }^{33}$ The other role is that of a private person who is not commanding in the name of a supreme authority. Their commands do not belong to the territory of positive law, only to that of positive morality.

The idea of sovereign being legally illimitable raises the question of the possibility of political freedom, i.e., distinguishing free and despotic governments (political powers). 'I answer that political or civil liberty is the liberty from legal obligation, which is left or granted by a sovereign government to any of its own subjects: and that, since the power of the government is incapable of legal limitation, the government is legally free to abridge their political liberty, at its own pleasure or discretion. ${ }^{34}$ Beside the freedom of sovereign government, the freedom of citizens can also be discussed. The latter, of course, is derivable from the former. 'Freedom, Liberty, are negative names, denoting the absence of Restraint. Civil, Political, or Legal Liberty, is the absence of Legal Restraint. [...] It is general or particular: i.e. it extends to all; or it is granted to one or some, by an exemption or privilegium [...]. Liberty and Right are synonymous; since the liberty of acting according to one's will would be altogether illusory if it were not protected from obstruction. There is however this difference between the terms. In Liberty, the prominent or leading idea is, the absence of legal restraint: whilst the security or protection for the enjoyment of that liberty is the secondary idea. Right, on the other hand, denotes the protection and connotes the absence of Restraint. If the protection afforded by the law be considered as afforded against private persons, the word Right is commonly employed. If against the Government, or rather against some member of the Government, Liberty is more frequently used; e.g., the Liberties of Englishmen. ${ }^{35}$ If the source of freedom is (governmental) power, this (power) character will also be kept by individual freedom. 'And, in that sense, a right may be styled a power. But, even in this sense, the definition will only apply to certain rights to forbearances. In the case of a right to an act, the party entitled has not always (or often) a power.' 36

Austin calls privilege an exemption from the generality of a law or a rule. The distinction between two sorts of privilege: the first imposes a duty to determinate person or persons and the second confers a right 'against the world at large' i.e., against the whole

\footnotetext{
32 Austin (1911) 288.

33 Austin (1911) 180.

34 Austin (1911) 274, Lecture VI.

35 Austin (1911) 356, Lecture XII.

36 Austin (1911) 398, Lecture XVI.
} 
community. ${ }^{37}$ In Austin's Lectures there is the concept of Power as manifestation of giving commands, the transferability and limitability of commands, Duty stemming from a command and Right correlative to it, Freedom stemming from the lack of power coercion and Privilege, giving exemption from it.

\section{2.}

Ernst Rudolf Bierling (1841-1919) may not be regarded a representative figure of NeoKantianism but rather as prominent in method-clarity, he can be rated to that stream of legal thought. ${ }^{38}$ In this regard two of his books bear significance. ${ }^{39}$ Bierling defined his subject of research as 'not a search for some right measure in order to evaluate positive law, but a search for the essence, the effectivity and the binding force of positive law itself.' He went on, claiming that 'the conceptual constituents of the positive, alone only valid, or which is the same: legally understood law cannot be derived from some moral law or ethical principle, exclusively only from scrutinising those norms, which are, or were, beyond peradventure positive legal norms. This is the only way to build up the conceptual specification, built upon the foregoing foundation; and this is the way of refuting or correcting it. Only a conceptual definition formulated this way can be useful for a science of law. ${ }^{40}$ No doubt, this claim is an analytical credo. Even if his starting point resonates with that of Austin's and it would have been possible for him to get inspiration from Austin, there is no sign of such an impact among Bierling's notes or references. ${ }^{41}$

Bierling's starting point was the distinction of subjektives Recht (subjective law $=$ right) and objektives Recht (objective law $=$ sum of the laws). Despite the suggestion of these terms, they do not mean that rights are within, within our 'soul' while the laws can be found somewhere outside, in the world. On the contrary, both rights and laws are objectively given from outside and from above, but, at the same time, they both are given as a form of the view of law [eine Form unserer Anschaunng vom Rechte] because law, such as all other products of 'spiritual life' [Geistesleben], has its own existence within spiritual beings, i.e., subjects of law [Rechtsgenossen]..$^{42}$ It is also characteristic of Neo-Kantianism to locate the existence of law in the sphere of spiritual being [Sollen] instead of natural or empirical world [Sein]. 'And this being is more accurately viewed as double: each norm of law is wanted or recognised on one side as legal claim [Rechtsanspruch], on the other as legal duty [Rechtspflicht]. In other words - each norm earns its content from legal relations [Rechtsverhältnisse] i.e., relations between claimants and obligants and vice versa everywhere where there are legal relations, their content, correlative legal claims and legal

37 Austin (1911) 96, Lecture I, note (a).

38 See e.g. Stolleis (1999) 163. (14.2.2.: "Österreich und die 'Wiener Schule'.”)

39 Bierling (1877-1883); Bierling (1894-1917).

40 Bierling (1877-1883) vol. 1. 162.

41 Most of Bierling's references point to German language sources; next, naturally, to Latin; sporadically to French, Italian, Spanish ones; only a single reference to Bentham, citing one of his examples but not leaning on it. Among the 53 authors occurring on Austin's list of readings 10 can be identified in the name index of Prinzipienlehre...; English authors are represented by Jeremy Bentham and John Stuart Mill. The fact that a stream of Neo-Kantianism fits Austinian analytics may be owing to the fact that Austin studied Continental jurisprudence, and of the authors of the 53 books donated by Sarah Austin to the Inner Temple, only nine are English, all the others are Continental scholars.

42 There is no proper equivalent of Rechtsgenosse in English. It does not have the meaning of 'subordination' to law, instead fellowship or membership of the same legal community - sort of 'lawmates'. 
duties [die korrelaten Rechtsansprüche und Rechtspflichte], becomes objectified in the form of norms and that is why certain objective law can be spoken off. ${ }^{43}$

The difference between objective law and subjective law is not simply identical with the relation between governmental legislation and self-regulative customary law of private autonomies. However, the state appears not just in the role of norm-positing, but also as subject of legal relations. This means that 'subjects bound by prescriptions of objective law are not only obligated by the law individually or collectively towards the higher authority standing behind the rights, but they may have similar legal claims and legal duties towards each other, as well; similarly as we can speak of legal claims of subordinates towards superiority, legal claims of members of political community towards the state. ${ }^{24}$

The equivalent of subjective law [Recht im subjektiven Sinne] is legal claim or claimright [Recht eines Subjektes] which is in its entirety positive law, as its content is provided by a norm, marking the correlative obligant together with the claimant. This also means that 'the aim of each legal claim is certain outer human behaviour; its content is the law i.e. one or more positive and self-reliant norms of law', ${ }^{45}$ and what the common or legal usage calls 'law in subjective sense' [Recht im subjektiven Sinne] fits this definition if and only if legal duty is attached to it. However, the word right is used with three different meanings:

1. entitlements against others behaviour

2. entitlements regarding our own behaviour

3. entitlements to cause certain legal effects in relations to others.

In the first case, right is identical with what is called legal claim [Anspruch]. In the second case right means sheer freedom [Dürfen] or permissibility and finally, in the third usage right means a definite legal capacity [rechtliches Können]. ${ }^{46}$ This capacity is not $a b$ ovo legal - it can be a natural human or social capacity of taking effect on others positions, relations or actions by behaviour. It only takes legal quality if the impact brought forth involves some claim or duty.

The system of Bierling's concepts of rights can be summarised as follows:

\begin{tabular}{|c|c|}
\hline Type of subjective law (right) & Correlative of subjective law (right) \\
\hline $\begin{array}{c}\text { (rechtliches) Anspruch (Rechtsanspruch) } \\
\text { claim for someone else's doing/forbearance }\end{array}$ & $\begin{array}{c}\text { (rechtliches) Pflicht (Rechtspflicht) } \\
\text { duty to do/forbear something (= Sollen) }\end{array}$ \\
\hline $\begin{array}{c}\text { (rechtliches) Dürfen } \\
\text { freedom to do/forbear something } \\
\text { lack of legal command or prohibition } \\
=\text { lack of Pflicht }\end{array}$ & defence against someone's interfering into freedom \\
\hline $\begin{array}{c}\text { (rechtliches) Können } \\
\text { capacity to bring forth claim/duty for others/ } \\
\text { oneself to do/forbear something } \\
=\text { entitlement/empowerment }\end{array}$ & $\begin{array}{c}\text { (rechtliches) Pflicht } \text { - only if some claim } \\
\text { is involved in or attached to Können }\end{array}$ \\
\hline
\end{tabular}

Table 2. Bierling's concepts of rights

43 Bierling (1894-1917) vol. 1. 145.

44 Bierling (1894-1917) vol. 1. 154.

45 Bierling (1894-1917) vol. 1. 161-2.

46 Bierling (1894-1917) vol. 1. 162.

47 The word 'right' is used in the sense of 'Können' in two cases: exclusively for or together with self-obligation. Bierling (1894-1917) vol. 1. at 182-3 offers examples for both cases. Examples of the former case are the right to indebtedness or the right to disclaim; examples of the latter are the owner's right to sell his/her ownership or the owner's right to put his thing in pawn. 
4.

The basic structure of the relation between right and duty was established by John Austin 'In short, the term right and the term relative duty signify the same notion considered from different aspects. Every right supposes distinct parties: A party commanded by the sovereign to do or to forbear and a party towards whom he is commanded to do or to forbear. The party to whom the sovereign expresses or intimates the command, is said to lie under a duty: that is to say a relative duty. The party towards whom he is commanded to do or to forbear, is said to have a right to the acts or forbearances in question.' ${ }^{48}$ The same basic relation between Rechtsanspruch and Rechtspflicht was also introduced by Bierling. This is the foundation on which Hohfeld's and Somló's buildings have been erected, even though their buildings differed from their forefathers' ${ }^{49}$

\section{1.}

What Hohfeld added to Austin's right-duty correlative is the extension of correlativity to four different pairs of 'right-duty' relation and the addition of (logically necessary) pairs of opposition, as oppositions are derived from types of rights by logical negation. ${ }^{50}$ Hohfeld 'tidied up' the room of rights. He separated, cleaned and defined both legal advantages (rights) and disadvantages (duties). The four types of rights were defined as:

1. (claim-)right;

2. privilege (freedom, liberty);

3. power;

4. immunity.

Their opposites are respectively

1. no-right;

2. duty (no-freedom);

3. disability (no-power);

4. liability (no-immunity).

In the table of advantages could be found such words as privileges, immunities, liberties, powers, abilities, capacities, interests, claims, exemptions, demands; in disadvantages table were words like duties, liabilities, inabilities, disabilities, defects, obligations. ${ }^{51}$ The crystallisation point was obviously right in strict or proper sense accompanied by (claim for) duty. Next two demarcations had to be carried out: first right (sensu largo) without duty - this is privilege; second right (sensu largo) without duty but with liability - this is power: distinguished from right-duty jural relations, ${ }^{52}$ but being able to intervene in such relations at will. Finally using the logic of opposites and correlatives

48 Austin (1911) 395, Lecture XVI (emphasis added).

49 The link between Bierling (and other German authors, like Windscheid and Kohler) and Hohfeld was provided mainly by Terry (1884) $108-128$ and Salmond (1902) $\S \S 70-78$. See e.g. Page (1921) 616 ff; Dainow (1934) 265-67.

50 Kanger \& Kanger replace the term 'correlative' with a - more correct - term of 'inverse'. They build up a complete conceptional system of the concepts 'rights', 'inverses' and 'negations'. For details see Kanger (2001) vol. 1. 120-145.

51 See e.g. Maher (1965) 48.

52 The adjective 'jural' instead of 'legal' was introduced by Terry and taken over by Hohfeld. 
the two Hohfeldian Tables can be built up around right and power. These tables are regarded complete in themselves and separated from each other, so there is no relation between the relations of the tables.

As already mentioned, Hohfeld's tragically short life did not allow him to extend and complete his work. In his 1913 Some Fundamental Legal Conceptions... he delineated his plans: he contrasted legal conceptions to non-legal ones; operative facts to evidential ones and fundamental jural relations were contrasted with one another. Of these he started to elaborate legal conceptions in order to classify fundamental jural relations as summarised in his tables. The 1917 Fundamental Legal Conceptions... was intended to be a continuation of the former. Hohfeld sketched here the structure of elaboration of relations between legal conceptions. He planned to discuss the same classification applicable to each of his eight legal conceptions defining relations:
1. in personam ('paucital') - in rem ('multital');
2. common (general) - special (particular);
3. consensual - constructive;
4. primary - secondary;
5. substantive - adjective;
6. perfect - imperfect;
7. concurrent - exclusive.

In another dimension, he also planned to interpret these classifications in relation to four objects:
a) rights;
b) judicial proceedings;
c) judgments or decrees;
d) enforcement.

What Hohfeld accomplished in 50 pages of 1917 Fundamental Legal Conceptions..., was only part 1. a of his plans - he analysed (primary) rights as in personam and in rem rights. Extrapolating this to the whole of Hohfeld's plan means that his work would have been an analytical opus of some 1,000-1,200 pages. ${ }^{53}$

The use or applicability of Hohfeld's terms is limited, mostly due to him being a private lawyer. ${ }^{54}$ This has become true especially for those working in legal praxis and trying to lean on his terminology. ${ }^{55}$ True, Hohfeld extended the validity of his rightsconcepts from the mainland of civil or private law (property law and contract law) to tort law (rights = claims against personal injuries, being confined, defamed, defrauded) but torts

53 Remember: Austin elaborated cca. 10 per cent of his draft lectures.

${ }^{54}$ Both in practice and in research Hohfeld was involved in areas of equity, conflict of laws, corporation law, trusts, individual liability of stockholders; at the time of his death he was preparing casebooks on trust, evidence and conflict of laws. See his obituary: Editorial (1918) 168.

55 One of the reports blames Hohfeld for he was '...concerned principally with the legal relation as a double-ended affair, with obligations and rights and powers and disabilities arising in the civil law, in contract and tort. He was not concerned to examine either the criminal law nor that area of constitutional law which, in particular, seeks to specify and to protect what are considered to be the fundamental rights of the individual. Moreover, he was not prepared to admit that either a right or duty could exist alone, without its corresponding correlative.' Goodwin-Gill (1976) 6. Similar criticism can be read from the theoretical side, missing the context of state from the concept of 'power'; see Joseph Raz (1972) 78. 
are still within civil law in the sense that bearers of rights and duties are individuals or groups of individuals - and not the state (sovereign). ${ }^{56}$ The main difference is between symmetrical jural relations of civil law and asymmetrical relations between authoritative bodies of governments and their subjects. One consequence of this is that in the case of undirected duties (they were called absolute duties by Austin) which are characteristic of penal law and public law in general - there is no definite correlative pair to the duty. ${ }^{57}$

'Yes, Hohfeld still matters' - Addo answered his own question. ${ }^{58}$ Overwhelming the possible fallacies or deficiencies of Hohfeld's work, two enduring results of him deserve appreciation. First, his contribution to raising the scientific level of jurisprudence to a height where it can efficiently contribute to social development. Not the taxonomy of rights in the first place but the commitment to achieving social reforms via legal reforms via legal science was Hohfeld's real inheritance from Bentham. ${ }^{59}$ Second, even in present days, his work serves as a basis and starting point for the efforts of better understanding ${ }^{60}$ and of formalizing concepts of rights. ${ }^{61}$ This results from the fact that he made a lasting impact not only on the language of law but also to the language of logic. ${ }^{62}$

\section{2.}

Somló started his scholarly career in sociology, studying interrelations between social facts, wistful for reforms, and legal norms (introducing social reforms) but he arrived at his opus magnum at much higher level of abstraction. The title of chapter 1. of his Introduction to Juristische Grundlehre is 'The task' ('Die Aufgabe') and the task was to unfold the form of law and elaborate its concept, instead of studying its content. ${ }^{63}$ In search for the concept of law, Felix Somló turned towards the concept of right and related concepts within his Juristische Grundlehre, in Chapter XIII ('Legal duty and legal claim', pp. 430-497). The momentum of his interest is similar to that of his analytic fellows - the confusion with the word right. The meaning of the word Recht is overladen, says he as it is used to refer to:

1. the whole system of legal norms ('Rechtsordnung');

2. individual rules of law ('objektives Recht');

3. norms of morals ('Rechte im ethischen Sinn');

4. the claim stemming from a norm of law ('subjektives Recht');

5. claims stemming from non-legal, conventional norms ('subjektive Konvention oder Sitte').

56 '...the same points and the same examples seem valid in relation to all possible kinds of jural interests, legal as well as equitable, - and that too, whether we are concerned with 'property', 'contracts', 'torts', or any other title of the law.' Hohfeld (1923) 26.

57 See e.g. Hart (1982) 182-3.

58 Addo (1997).

59 'The picture that emerges from Hohfeld's address is mainly Benthamite in spirit. [...] the result would be a massive improvement in the functioning of law and legal institutions. Moreover, Hohfeld seemed to suppose that comprehensive legislation would and should be the primary mechanism through which law reform would occur.' Goldberg (2017) link 3. 16. To be published in Balganesh et alii (2018).

${ }^{60}$ E.g. d'Almeida (2016) link 4.

${ }^{61}$ E.g. Markovich (2017).

62 See Allen (1998). What is more, Balkin (1990) 1120 calls him 'the first legal semiotician'.

63 That is why he passed strictures on Bergbohms 'most general' jurisprudence ('allgemeinste' Rechtslehre) which had been built on general concepts drawn off content of systems of law. Somló (1917) 11. 
'This terminology is to be blamed for the fact that the concept of legal claim, which is not only equivalent to right ['subjektives Recht'], but superior to it, has been overshadowed by careful elaboration of rights in legal scholarship. ${ }^{94}$

It should be stressed that the main reference in this book of Somló is Austin, together with his central conception and role of sovereign. The first step in Somlós conceptual construction is the concept of law ('Recht'), the genus proximum of which is the norm, ${ }^{65}$ while the differentia specifica is the source of these norms - the supreme i.e., legislative, power of society. This power is the Rechtsmacht for Somló, with close similarity to Austin's sovereign. Chapter II of Grundlehre describes it with features such as 'it is able to carry its commands within a certain circle of people more commonly and efficiently than other powers'; 66 'it enacts a large number of positive norms, which extend its power over a wide field of subjects life relations [...] and which are integrated into a system of law [Rechtsordnung]';67 'existence of this system of law shows continuity.' ${ }^{68}$ All this foreshadows the interpretation that Somló's approach to rights is biased by his focus on public law. If the concept of law is specified by Rechtsmacht then the existence of rights are to be derived from the use of this (legislative) power and the use of power is to command and to oblige.

This is the source of Somló's rights conception - 'The concept of legal duty is one of the most elemental constituents of the concept of law and it resides already within the genus proximum of law.' ${ }^{69}$ The first set of concepts cover the realm of law', i.e., the sum of norms - positives Recht. Each of the norms imposes some duty, 'The meaning of each norm contains the sense of ought ['Sollen'], i.e. it puts duty on the addressee of its ordainment. ${ }^{70}$ What is new, Somló defines two sets of subjects, i.e. obligants, beside the subjects of sovereign he counts with the possibility of self-obligation of the legislator. ${ }^{71}$ This division results in a new distinction within positive law: commanding law (Befehlsrecht) and promissory law (Versprechenrecht). Commanding law contains a command, addressed by sovereign to subordinates; promissory law contains a promise, addressed by sovereign to itself. $^{72}$

The second stage of concepts covers the realm of right i.e., the sum of legal positions: subjektives Recht. Both from a commanding law and from a promissory law some duty follows: command-duty (Befehlsverpflichtung) and promise-duty (Versprechensverpflichtung), respectively. ${ }^{73}$ Duty is one side of a relation - the other side (Somló does not

64 Somló (1917) 468-69.

${ }^{65}$ Maybe not the 'command' like for Austin, but a 'norm' is nothing else than the result of the command of the legislative power.

66 Somló (1917) 93.

67 Somló (1917) 97.

68 Somló (1917) 102. Somló's final definition of law is as follows: 'Law means the norms of a supreme power, being usually obliged, comprehensive and persistent' $i d .105$.

69 Somló (1917) 432.

70 Somló (1917) 430.

71 This was declared impossible by Austin and it remained out of Hohfeld's sphere of interest.

72 For detailed analysis of Somló's conception see Ződi (2016).

73 “'Only commanding norms ('Befehlsnormen') impose duty on legal subordinates, promissory norms ('Versprechensnormen') impose duty on promissor, in our case the sovereign itself..." Somló (1917) 432. 
call it correlative) is called claim (Anspruch) ${ }^{74}$ These concepts define three basic subjective relations (fundamental legal relations in Hohfeld's words) between norm-maker and normsubject: command-duty, promise-duty and promise-claim. ${ }^{75}$ Of the three only the first is necessary, because without command no law exists, while it may exist without promise. ${ }^{76}$ Furthermore two kinds of duty may stem from a command: primary and secondary command-duties. Somlós example is the command alimony: the obligant of alimony owes the legislative power their primary duty and, at the same time, they owe the beneficiary secondary duty. Two different claimants are entitled to raise the same claim against the obligant, who may gratify both claims by the same action: the payment of alimony. The secondary claimant is in the legal position of claim-right in Hohfeld's terms. ${ }^{77}$

Though Hohfeld referred to the political sense of power time to time, he excluded it from his investigations as not being a legal concept. Somló does not and takes political power (Rechtsmacht), as one of the agents (actually, the most important agent) of law and legal relations. When promising the Rechtsmacht (legislator, sovereign, state, government etc.) is the chief agent of the other two basic subjective relations: promise-duty and promiseclaim. They refer to different aspects of the same action of Rechtsmacht: the first as its own action and the second as the subject's claim to the same action. Correlatively, the beneficiary of a norm (if there is any) has two separate kinds of claim: The claim against the obligant to exercise their duty (this is a secondary command-claim for Somló) ${ }^{78}$ and the claim against the state to intervene and enforce in case the obligant does not exercise their duty. ${ }^{79}$ The latter is called petition-claim (Klageanspruch) by Somló - the right to bring an action and receive a decision.

As the next step in his conceptual construction Somló introduces the distinction active and passive behaviour as the object of norms, which is specifically important in case of promissory norms. The sovereign promises activity in case of a petition claim, at the wish

74 "We are going to call this relation assignment from the norm-maker's point of view, while 'claim' (Anspruch) from the recipient's point of view." Somló (1917) 440 Somló refers to the works of Kant, Radbruch, Binder, Bierling, Stammler and Kelsen when analysing the concept of 'duties' and to Austin, Schmidt, Merkel, Jellinek, Kelsen and Holland regarding the concept of 'claims'.

75 Note that Hohfeld does not take into regard any relation between norm-maker and normsubject, only relations between norm-subjects.

76 'As, on the one hand, no norm of law may exist without imposing some duty, so this is a necessary subjective aspect of norms of law; on the other a legal norm does not necessarily ensure a claim, either, so this is only a possible subjective aspect of norms of law - it follows that claim and duty are not correlative concepts, they are not simply two sides of one and the same thing...' Somló (1917) 444 (emphasis added) Somló makes this statement because he (together with Austin) warns that no one can give anything him/herself - nor can the sovereign confer or ensure claim to itself, even if this were a claim to obey its norms.

77 'Primary command-duties ('Befehlsverpflichtungen') are amended with secondary ones. Their contents are the same, their difference rests only in that the obligant owes different agents certain behaviour. Primarily: the sovereign; secondarily: one (or more) subordinate(s) of it. [...] It means that secondary legal duties are correlative with the claims of beneficiaries. In order to demarcate such claims from primary claims, stemming from promissory norms, we shall call them secondary legal claims or command-claims." Somló (1917) 441-2.

${ }^{78}$ Remember, Somló does not recognise primary command-claims - the claim of Rechtsmacht for its norms being accomplished.

79 The two kinds of claims must and can be separated: in case of lex imperfecta (duty without sanction) the claimant possesses duty-claim without petition-claim. Somló (1917) 448. 
of the injured party. ${ }^{80}$ On the other side: 'If the Rechtsmacht promises to stay passive within certain circumstances, we call the claim stemming from this promise freedom (Dürfen), the assurance of this freedom to somebody is permission (Erlaubnis). ${ }^{81}$ Freedom is not pure or natural freeness from constraints, but it is a legal position: 'Freedom in its legal sense means freedom from the intervention of Rechtsmacht, it refers to a territory of human activity and life-relations where the sovereign made a promise not to intervene. ${ }^{82}$ The bearer of freedom is allowed to do or to refrain from doing anything, without fearing state intervention. A wider interpretation of promise duty and promise claim would make it possible to handle the problem of civil liberties or basic rights as (self-)constraints of states. They are touched upon by Somló under the title 'subjective public rights' ${ }^{93}$ - briefly and mostly by referring to Jellinek's classification of these rights:

1. promises of the state to forbear;

2. promises of the state for services;

3. promises of the state as operator of organs.

The work/plan ratio in Somló's case was just the opposite of Hohfeld's. As already mentioned, in addition to the 420 pages of Hohfeld's publications a plan of $c c a$. 1,0001,200 pages can be estimated. Somlós published papers total up to 2,200 pages - scattered over a wide range from texts of a few pages to vast monographs, but it is hard to say how well-grounded they were. Originally he wanted to elaborate three theoretical aspects of law: the factual foundations of law i.e., sociology, his main topic up to 1910; the conceptual foundations of law i.e. Grundlehre 1910-1917; and axiological foundations of law i.e. Wertlehre which remained unrealised. Instead he turned towards some Kantian metaphysics ${ }^{84}$ which did not prove successful. He framed the steps of his plan ${ }^{85}$ with the only result being

80 This kind of promise-claim can be called Können, referring to the claimant's free choice about whether or not they want to take the opportunity. Somló himself does not use this term, though he (critically) refers to Jellinek's usage: Somló (1917) 458-9. Jellinek - staying within the sphere of private law - himself identifies 'Dürfen' with those permitted (erlaubt) behaviours which may bear some legally relevant impact on others: Jellinek (1892) 43. Dürfen is one part of action we 'can do' together with but contrasted to further meanings of 'can'. First we often speak of what we "naturally can' (naturliches Können) i.e. what we are physically able to do; second of what we 'legally can' (rechtliches Können) i.e. what we are able to do as legally valid acts. His example is legal incapacity: a child is (physically) able to sign a contract; he is not forbidden, so he is allowed (er darf-Dürfen) to sign it; but whatever he does the result will not be a legally valid contract, so he can (er kann Können) sign no legally valid contract. So: 'The legally relevant capacities provided by a legal system in their totality form the legally can (rechtliches Können).' Jellinek (1892) 45.

81 Somló (1917) 451. In Hungarian Somló uses 'szabadság' (= freedom, liberty) for 'Dürfen'. The term came from Bierling as one constituent of his terminology and its content was elaborated by Somló after analysing respective concepts of Austin, Bierling, Jellinek and Kelsen. Somló himself translates it as 'Freiheit': 'Das Dürfen ist das Gebiet der Freiheit der Untergebenen.' (Dürfen is the territory of the freedom of subjects.) Somló (1917) 451.

82 Somló (1917) 452.

83 Somló (1917) 494-7.

84 'The whole wide empire of philosophy reveals itself for me as such in which I climb the heights of Kantian thoughts step by step.' Somlós Diary vol. 3. 17 Okt. 1916.

85 'Positive [philosophy]: 1. Metaphysics of thought, 2. Logics, 3. Moral philosophy; Critical [philosophy]: 4. Theory of religion, 5. The possibility of philosophy of history, 6. »Philosophical« aesthetics, 7. »Philosophy of nature«.' Somlós Diary vol. 3. 4-15 March 1917. 
an uninfluential 100-page posthumous booklet. ${ }^{86}$ This may account for the final summary in the obituary for him - 'His almost twenty-five-year-long work advances in zigzags, time to time with breaks, instead of continuity, his manifestations are fractional and all that is the reason why it is so hard to give a favourable account of his philosophy as he had, perhaps not as elaborated systems, just as drafts, more than one. ${ }^{87}$ However, coming to a sticky end should not darken the magnitude of Somló's opus magnum, which made him the most known and respected Hungarian philosopher of law. ${ }^{88}$

\section{5.}

Somló and Hohfeld moved in two different lanes. They did not confront nor did they meet. However, the bend of their lanes were parallel. The destination was the same - to clean up the concept of right and of neighbouring concepts. Following our initial metaphor, it can be said that Hohfeld proceeded on the road of Anglo-American law, Somló on the road of the Roman-German law family. Furthermore, Hohfeld chose the lane of private law whilst Somló was interested in public law. It followed that Hohfeld left out the problems of public law that formed the basis for Somló and also that Hohfeld forgot about public promises of governments while Somló did not care much about private promises, i.e. contracts. The models they have arrived at proved to be similar and different at the same time. Both organised logically coherent systems of concepts of elemental legal positions, though Hohfeld arrived at a dyadic model of oppositions and correlatives; Somlós model was triadic: certain interrelations between command, promise and claim. Hohfeld summed up the relations among his concepts of legal positions in two tables; Somló did not do that, but did lay down the conceptual basis on which we may try to suggest Somló's tables parallel to Hohfeld's. That will be the papers conclusions.

As widely known Hohfeld separated eight elemental legal concepts - four kinds of rights and four kinds of duties - organised around two fundamental concepts: right and power. The first table consists of right, its opposition (negation): no-right and their correlative (equivalent) pairs: duty and privilege/freedom/liberty. The second table is organised the same way around power. ${ }^{89}$ Constituents within tables have no cross-table relations with constituents of the other table. The standard answer to the question of the relation between tables is that while the terms of the 'right' table apply to behaviours between partners of relations, the terms of the 'power' table apply to capacities of partners of relations to intervene and determine the legal position of the correlative partner.

86 Somló (1926).

87 Bárd (1921) 33.

88 It is worth noting that Somló is not the only scholar of his time paying attention to the topic of legal positions. The Roman and private lawyer Gusztáv Szászy-Schwarz in his 'A jogi helyzetek' (Legal positions) classifies possible legal relations between bearers of active and passive legal positions: 1. unsusceptibility: protection of someone's interest via someone else's duty; 2 . subjective right: claim-right; 3 . power: capacity to bring forth some legal effect; 4 . freedom: exemption from some command or interdict; 5. expectancy: till the realisation of one of the mentioned possible positions, the legal appreciation of that remainder. During the exposition the names of Windscheid, Jhering and Dernburg are mentioned, without deeper theoretical commitment. See in Szászy-Schwarz (1912) 391-412.

${ }^{89}$ The basic, organizing concepts are printed in capital letters in the tables; which are right and power for Hohfeld, and promise and command for Somló ' $\mathrm{A}$ ' and 'B' are the partners (subjects) of definite legal/jural relations. 


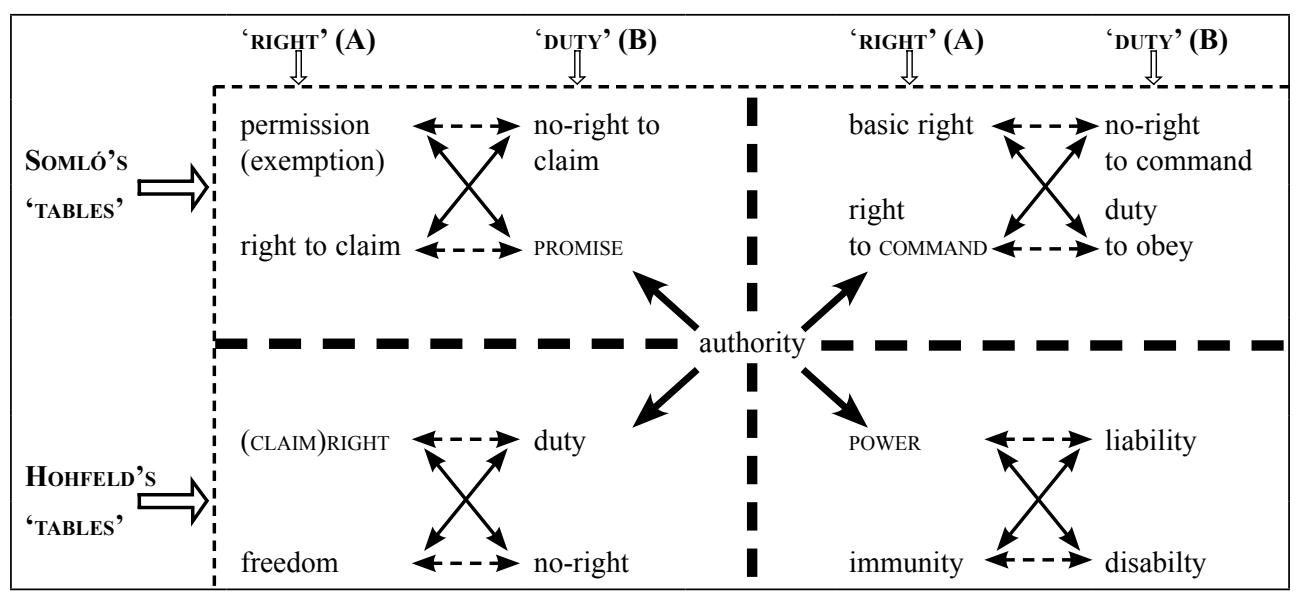

Table 3. Somló's and Hohfeld's tables

Hohfeld does not take into regard the authority (sovereign, state, government, legislator, positive law) because it is held by him to be a political (not legal) concept. It follows that he cannot and does not point at the sources of right and power - although a right in fact is right to claim, the source of which is entitlement by authority, entitlement to claim. In the same way, power in fact is empowerment by authority, again. That is why a correction in Hohfeld's conception is suggested by inserting the concept of authority into the organising middle. This will slightly modify Hohfeld's tables; the central concept of the first table will be duty instead of right - in coherence with classics of the analytical school and with the insight that the state is not able to enforce rights, only duties and power shall be understood as empowerment because now there is the origin of this power.

Somló's tables may be added to Hohfeld's first- and second-order tables as third- and fourth-order ones. They may be originated from authority in the same way as Hohfeld's, mirroring and transposing his relations. This way legal positions named by Somló are able to be arranged into relations of oppositions and correlatives. Of course, this results in slight modification of or, rather, proceeding in Somló's conception:

1. Now, Somló has shown that authority may either command or promise and these become the two organising concepts of his tables.

2. The correlative of authority's command is the duty of addressees to obey: the basic relation of public (constitutional, administrative, penal) law. The addressees are either organs or officials stepping up in the name of authority/law, or subordinate subjects of law. Their legal position is duty: The legal duty to obey enforced by sanctions. The source of the right of authority to command lies outside of law: in politics and its political entitlement to command is conveyed into law's territory via constitution. The negation of right to command is the absence of it, as the case is with basic or constitutional rights, like in the USA's Bill of Rights - 'the Congress shall make no law...'. No-right is legal, not sheer empirical position - it is the duty of authority to restrain from making law/command.

3. 'No-right' is the duty of lawmaker, which also has a correlative on the 'right' side of this duty. That side covers basic rights of subjects against authority. Though there are systems of constitutional muster or revision by constitutional courts (or some functional equivalents) and subjects may initiate such supervision, their right is not claim-right in the proper sense. The possibility of initiation can be better understood as signalization, instead of enforcement of a claim or demand. 
4. With its promise the authority takes the duty of intervention (by its organs) at the will of its subjects (which is sort of public law liability) - it promises activity. That the sovereign might impose duties upon itself or invest itself with rights seemed to be impossible for Austin and it was no point for Hohfeld. As correlative pair of promise-duty the subjects have the right to claim the intervention and (fair) process (e.g. by instituting an action) of authoritative organs whenever the concluding facts occur. What happens is that the state who occupies the monopoly of legitimate coercion offers and in case lends its power to its subjects. The authority, of its own free will lets the subject rule over a small part of its power.

5. Finally, the negation i.e. the opposition of promise is no-promise- the state does not grant a piece of its power to any of subjects. This results in the withdrawal or dismissal of any (possible) promise, by giving exemption from an eventually existing promise. The correlative of no-promise, and, at the same time, to opposition of right to claim, is no-right to claim. If the authority promises to stay passive it ensures freedom for the subject, who can be sure about no rights to claim against them. This kind of no-right to claim is certain public law privilege in the form of permission. The beneficiary of some permission is promised that no one shall be allowed to launch a claim against them.

Drawing a final conclusion from the comparison of life and work of these two outstanding scholars one hundred years later shows the complementary nature of their parallel workings. Not knowingly, they laboured on the same work, constructing two halves which when put together make a whole. In order to arrive at this final conclusion, the missing link - the concept of political authority - needed to be added. This was missing (or avoided) in Hohfeld's conception but could be found in Somlós theory in the form of Rechtsmacht. Rechtsmacht is legal power i.e., political power absorbed by and inserted in law. As it is not above but within law, it can serve as fundamental concept for various kinds of rights and duties, as well. Of these rights and duties Hohfeld elaborated those which define legal positions and relations in the area of private law. In fact, his tables do not fit positions and relations of public law. Somló's part may be (re)constructed in such a way that it amends and fills the gap found in Hohfeld's system. After piecing the two parts together it shall be possible to model a full system of law. This job is not done in this contribution - the aim of this paper has only been to show that there exits such a possibility.

\section{LITERATURE}

Addo, Michael K., 'Does Hohfeld Still Matter?' (1997) 29 Bracton Law Journal 7-12.

Allen, Layman E., 'Some Examples of Using the Legal Relations Language in the Legal Domain: Applied Deontic Logic' (1998) 73 Notre Dame Law Review 535-74.

Austin, John, Lectures on Jurisprudence or the Philosophy of Positive Law vol. I ( $5^{\text {th }} \mathrm{edn}$, John Murray 1911).

Balganesh, Shyam, Sichelman, Ted and Smith, Henry E. (eds), The Legacy of Wesley Hohfeld: Edited Major Works, Select Personal Papers, and Original Commentaries (Cambridge UP 2018).

Balkin, Jack M., 'The Hohfeldian Approach to Law and Semiotics' (1990) 44 University of Miami Law Review 1119-42.

Bárd, József, ‘Somló Bódog’ (1921) 5 Jogtudományi Közlöny 33-36.

Bierling, Ernst Rudolf, Zur Kritik der juristischen Grundbegriffe vols. 1-2 (Friedrich Andreas Perthes 1877-1883).

Bierling, Ernst Rudolf, Juristische Prinzipienlehre vols. 1-5 (J C B Mohr 1894-1917).

Bowie, Andrew, German Philosophy: A Very Short Introduction (Oxford UP 2010).

Cook, Walter Wheeler (ed), Fundamental Legal Conceptions as Applied in Judicial Reasoning and other Essays (Yale UP 1923). 
Dainow, Joseph, 'The Science of Law: Hohfeld and Kocourek' (1934/5) 5 Canadian Bar Review $265-82$.

Dworkin, Ronald, Law's Empire (Harvard UP 1986).

Editorial, 'Wesley Newcomb Hohfeld' (1918) 2 The Yale Law Journal 166-68.

Funke, Andreas and Sólyom, Péter (eds), Verzweifelt objektiv: Tagebuchnotizen und Briefe des ungarischen Rechtsphilosophen Felix Somló (1873-1920) (Böhlau 2013).

Glock, Hans-Johann, 'Neo-Kantianism and analytic philosophy' in Warren, Nicolas de and Staiti, Andrea (eds), New Approaches to Neo-Kantianism (Cambridge UP 2015) 59-81.

Goodwin-Gill, Guy S., 'Uses and Misuses of Hohfeldian Analysis' (1976) 6 Kingston Law Review $3-10$.

Gray, John Chipman, Nature and Sources of Law (Columbia UP 1909).

Hanna, Robert, Kant and the Foundations of Analytical Philosophy (Oxford UP 2001).

Hart, Herbert L. A., 'Kelsen visited' (1962) 3 UCLA Law Review 709-28.

Hart, Herbert L. A., Essays on Bentham. Jurisprudence and Political Theory (Oxford UP 1982).

Hohfeld, Wesley Newcomb, A Vital School of Jurisprudence and Law (Ass. of American Law Schools 1914).

Hohfeld, Wesley Newcomb, 'Some Fundamental Legal Conceptions as Applied in Legal Reasoning' in Cook, Walter Wheeler (ed), Fundamental Legal Conceptions as Applied in Legal Reasoning and other Essays (Yale UP 1923).

Hohfeld, Wesley Newcomb, Fundamental legal conceptions, as applied in judicial reasoning (Yale UP 1964 [first published 1946]).

Jellinek, Georg, System der subjektiven öffentlichen Rechte (J. C. B. Mohr 1892).

Kanger, Stig and Kanger, Helle, 'Rights and Parliamentarism' in Holmström-Hintikka, Ghita, Lindström, Sten and Sliwinski, Rysiek (eds) Collected Papers of Stig Kanger with Essays on his Life and Work vols. 1-3. (Springer 2001).

Kelsen, Hans, Hauptprobleme der Staatsrechtslehre, entwickelt aus der Lehre vom Rechtssätze (J C B Mohr 1911).

Kelsen, Hans, 'The Pure Theory of Law and Analytical Jurisprudence' Harvard Law Review (1941) vol. 55 no. $144-70$.

Kelsen, Hans, General Theory of Law and State (transl. Wedberg, Anders) (Russell \& Russell 1961)

Laband, Paul, Staatsrechtliche Vorlesungen. Vorlesungen zur Geschichte des Staatsdenkens, zur Staatstheorie und Verfassungsgeschichte und zum deutschen Staatsrecht des 19. Jahrhunderts, gehalten an der Kaiser-Wilhelm-Universität Straßburg 1872-1918. (Bearbeitet und hrsg. von Bernd Schlüter) (Duncker \& Humblot 2004).

Maher, Francis Kevin Heathcote, 'The Kinds of Legal Rights' Melbourne University Law Review (1965) vol. 5 June, 47-75.

Markovich, Réka, Deontic Logic and Formalizing Rights (PhD Thesis) (ELTE [Eötvös Loránd University Budapest] 2017).

Page, William H., 'Terminology and Classification in Fundamental Jural Relations' The American Law School Review (1921) vol. 4. 616-23.

Pound, Roscoe, Jurisprudence vol. 1 (West Publishing Co. 1959).

Raz, Joseph, 'Voluntary Obligations and Normative Powers' Proceedings of the Aristotelian Society (1972) Supplement vol. 59.

Salmond, John William, Jurisprudence (Stevens \& Haynes 1902).

Singer, Joseph William, 'The Legal Rights Debate in Analytical Jurisprudence from Bentham to Hohfeld' (1982) Wisconsin Law Review 975-1060.

Sólyom, Péter, Jogászi módszer és politika [Juridical Method and Politics] (Gondolat 2016).

Somló, Felix, Juristische Grundlehre (Felix Meiner 1917).

Somló, Felix, Jogbölcsészet (Grill 1920).

Somló, Felix, Gedanken zu einer ersten Philosophie (Moór, Julius ed) (De Gruyter 1926).

Somlós Diary in 4 volumes. National Széchenyi Library Manuscripts, Quart. Hung. 3038.

Stolleis, Michael, Geschichte des öffentlichen Rechts in Deutschland vol. 3 Staats- und Verwaltungswissenschaft in Republik und Diktatur (C H Beck 1999).

Szászy-Schwarz, Gusztáv, Parerga: Vegyes jogi dolgozatok [Parerga: Miscellaneous Legal Papers] (Athenaeum 1912). 
Terry, Henry Taylor, Some Leading Principles of Anglo-American Law (T \& J W Johnson 1884).

Trejo-Mathys, Jonathan, 'Neo-Kantianism in the philosophy of law' in Warren, Nicolas de and Staiti, Andrea (eds) New Approaches to Neo-Kantianism (Cambridge UP 2015) 147-70.

Ződi, Zsolt, 'Az ígérő jog Somló Juristische Grundlehréjében' [The concept of promising law in Felix Somló's Juristische Grundlehre] Acta Universitatis Sapientiae: Legal Studies (2016) vol. 5 no. $2345-62$.

\section{LINKS}

1. Symposium on the Work of Wesley Newcomb Hohfeld (2016) <https://law.yale.edu/yls-today/ yale-law-school-events/symposium-work-wesley-newcomb-hohfeld $>$ accessed 20 March 2017.

2. Schlegel, John Henry, 'Wesley Newcomb Hohfeld: On the Difficulty of Becoming a Law Professor' (2016) University at Buffalo School of Law Legal Studies Research Paper No. 2016$036<$ https://ssrn.com/abstract=2897524> accessed 1 March 2018.

3. Goldberg, John C. P. and Zipursky, Benjamin C., 'Hohfeldian Analysis and the Separation of Rights and Powers' (2017). <https://ssrn.com/abstract=2894521> accessed 1 March 2018.

4. d'Almeida, Luís Duarte, 'Fundamental Legal Concepts: The Hohfeldian Framework' 11 Philosophy Compass (2016) no. 10 554-569 <http://onlinelibrary.wiley.com/doi/10.1111/ phc3.12342/full> accessed 1 March 2018. 